\title{
ANALYSIS OF URBAN GROWTH PATTERN AND SOCIOECONOMIC ASPECT AFTER THE TSUNAMI DISASTER: THE CASE OF BANDA ACEH, ACEH, INDONESIA
}

\author{
Ashfa Achmad 1 , Sirojuzilam², Badaruddin ${ }^{3}$, Dwira N. Aulia ${ }^{4}$ \\ ${ }^{1}$ Architecture Department, Syiah Kuala University, Aceh/Graduate School of Regional Planning, University of \\ Sumatera Utara, Sumatera Utara, Indonesia, ashfaachmad@yahoo.com \\ ${ }^{2}$ Economics Department, University of Sumatera Utara, Sumatera Utara, Indonesia, sirojuzilam@usu.ac.id \\ ${ }^{3}$ Sociology Department, University of Sumatera Utara, Sumatera Utara, Indonesia, badaruddin@usu.ac.id \\ ${ }^{4}$ Architecture Department, University of Sumatera Utara, Sumatera Utara, Indonesia, dwira@usu.ac.id
}

\begin{abstract}
Knowing the character of urban growth, especially the city which has been hit by tsunami, is an important issue in urban planning. This article reports the initial finding of the character of urban growth after tsunami disaster viewed from several aspects such as growth pattern, population, and urban economic development. This study employed descriptive analysis method based on the data obtained from the Central Bureau of Statistics and the satellite images of 2005 and 2009. The result of analysis showed that the urban growth after the tsunami lasted in infill and expansion basis. The population growth was not yet balanced with the growth of built-up area. The growth was influenced by population growth and economic development, even though it was not yet encouraging in reducing the rate of poverty. The growth of built-up area should be well controlled so that it has sufficient green space and cultural conservation areas to support sustainable development.
\end{abstract}

Key words: urban growth, population, socioeconomic, tsunami, Banda Aceh.

\section{INTRODUCTION}

The increasing of urban growth and land use changes as results of social and economic activities which were growing rapidly, have a broad impact on global change and has been a topic discussed in the academic field $[1 ; 2 ; 3]$. Socioeconomic and biophysics factors were the driving factors of urban growth $[3 ; 4 ; 5]$. By the development of technology and availability of spatial data, urban growth simulation has been developed, such as agent-based, cellular automata, and logistic regression methods, conducted by geographers, planners, and scholars, and shows a good potential to simulate complex urban growth and land use changes [6]. This increasing was marked by the transformation of land use/cover (LUC) to accommodate the growing of human activities [4].

The analysis of urban growth has been mostly done on a city or county that grow normally. Not many analysis regarding disaster-prone areas, such as Banda Aceh. Banda Aceh was hit by the tsunami on December 26, 2004 and almost a half of the city damaged. The quick development to remedy the situation and improve the quality of life made a significant increase of urban growth. Physically, it has experienced an increasing of built-up area more than 1.5 times between 2005 and 2009, for residential area, office building complex, infrastructures, and markets. In terms of economic condition, the average number of Gross Domestic Regional Product (GDRP) increased approximately 5\%/year (20052009). In terms of the population aspect, population increased an average of approximately 5\%/year between 2005 and 2009. Based on the population of 2005, it is estimated that the population will increase two times in 2020 This shows that Banda Aceh will keep growing to accommodate the needs and activities of community.

The growth experienced by this city focused on the aspect of the increasing of built-up area, infrastructures, and economic growth. Rapid growth to anticipate the needs of the posttsunami was feared to degrade the quality of the environment so that sustainable development will be difficult to achieve. Sustainable urban growth and smart growth are two of the objectives of growth control. The growth focused on the compact environment and urban area is the existence of smart growth [7;8]. Although urban growth is to achieve sustainable economic, uncontrolled or sprawling urban growth causes various problems [9], and what feared is that public welfare as the goal especially related to the comfort, safety and preservation of the city is hard to achieve.

Several studies focused on the urban growth have been done by researchers in several countries. Study of urban growth in China has been focused on the rapid growth in the major cities and coastal towns from different viewpoints $[2,3 ; 10]$. Likewise, studies conducted outside of China [5; 7]. Model predictions of growth are essential for good city planning. Urban growth prediction models can help to understand the mechanism of changes in land use and also will be able to help making appropriate policies [4], to support the growth 
of sustainable cities. Prediction of future urban growth scenarios created to better understand the urban dynamic and to support urban planning [3]. Shi et al put more emphasis on the character type in Lianyungang City urban growth, which found that the results indicated the prominent urban growth was edge-expansion type, most prominently with continued urbanization in the peri-urban areas [11].

The urban growth of a city hit by the tsunami is also important to be studied to assist in making the policy in materializing smart growth and minimizing the impact of earthquake and tsunami that its growth and land resources were controlled during the urbanization process. Tsunami can be a significant risk for the residents and cause a big damage in the coastal area [12] and can reoccur within a certain period of time [13]. A big tsunami can cause a disaster along the densely populated and up to several kilometers from the shore [14]. The tsunami occurred at that time have made about 170,000 the Acehnese and the Minangkabaus dead in the northern tip of Sumatera [15]. Sustainable development is the main goal of urban researchers and decision makers [3]. The purpose of this study was to identify generally the pattern of urban growth after the tsunami (2005-2009) and its relationship with socio-economic development.

\section{MATERIALS AND METHODS}

\subsection{Study Area}

This study was conducted in the administrative area of the City of Banda Aceh, Aceh Province (Fig - 1) which is geographically located between $5^{\circ} 16^{\prime} 15^{\prime \prime} \mathrm{N}-05^{\circ} 36^{\prime \prime} 16^{\prime \prime} \mathrm{N}$ and $95^{\circ} 16^{\prime \prime} 15^{\prime \prime E}-95^{\circ} 22^{\prime \prime} 35^{\prime \prime} \mathrm{E}$. This city has the area of 6,000 ha and its urban area is located on an average of 0.80 meter above sea level with the population of 228,560 in 2011. The position of the city of Banda Aceh is much closed to the subduction zone that it is very vulnerable to earthquake and tsunami [13].

Geographically, the location of the city of Banda Aceh is near the active Semangko fault [16]. Historically, most of the earthquakes occurred off the coast of Sumatera were the boosts at the mega thrust, like the one occurred in the Western Coast of Aceh on December 26, 2004 and the earthquake occurred in Nias on March 28, 2005 as well as the one occurred in September 2007 [13].

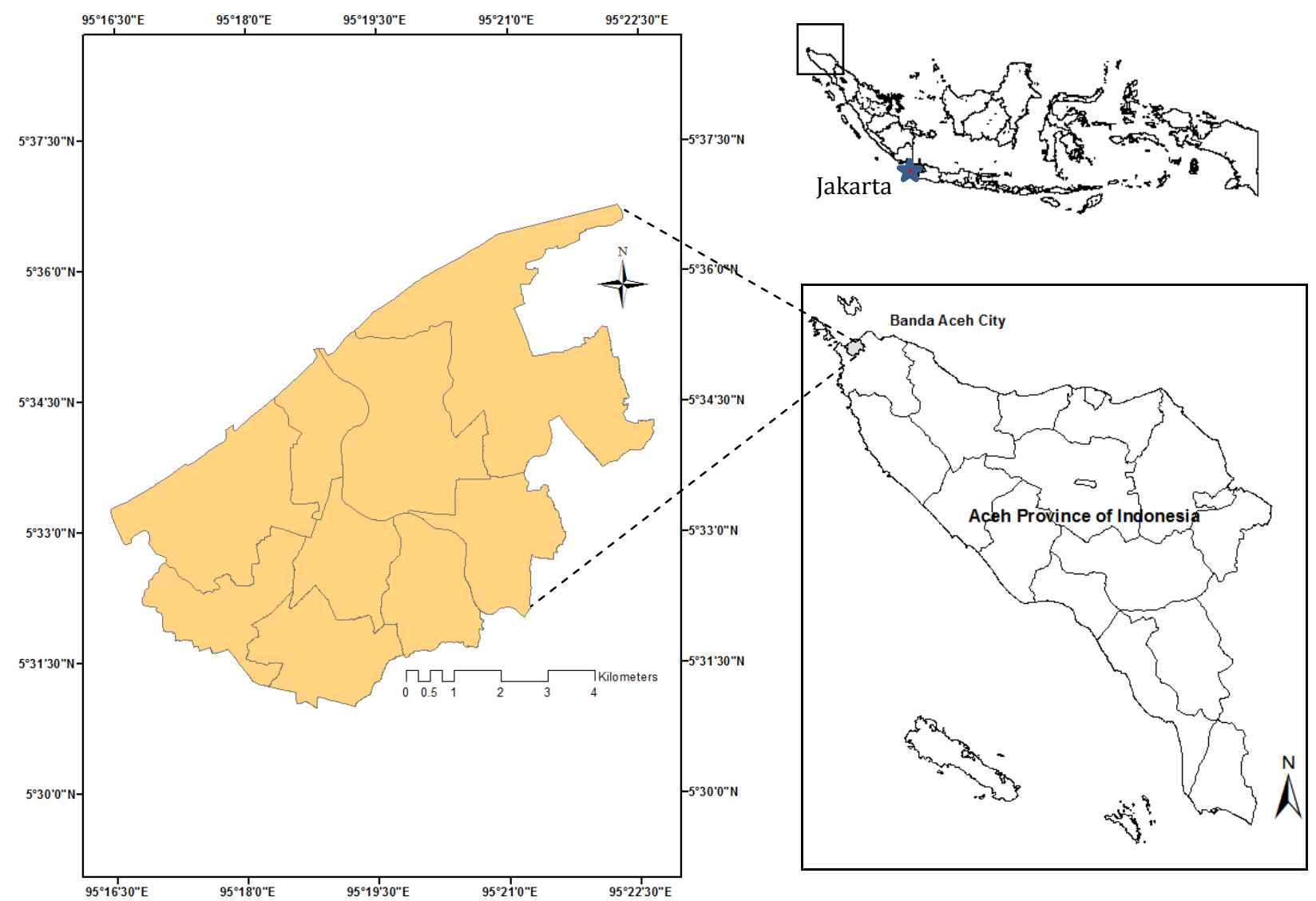

Fig - 1: Study Area of Banda Aceh 


\subsection{Methods}

Urban growth was determined by using a time series of satellite images of 2005 and 2009 and the data of resident population. The satellite images were obtained from Aceh Regional Planning and Development Board and the number of population was obtained from the Central Bureau of Statistics, Aceh Province. The land use classification of satellite imagery between 2005 and 2009 were analyzed by GIS. Geographic Information System (GIS) was very useful to facilitate and accelerate this process of urban growth analysis [17].

Study area, approximately 6,000 ha, sampled from satellite imagery based on the administrative boundaries of the Qanun no. 4/2009 of Banda Aceh Spatial Planning 20092029. Land category was divided into built-up area, non built-up area, and others. The built-up area includes concrete structures, like building pavement, houses, roads, bridges, and others. While the non built-up area includes undeveloped land. Others category was defined as water body, like river and sea, wet land, and the land which not identified, which are within the administrative area of the city. Growth rate is defined as the ratio of the growth of urban areas to population growth which can be calculated by the equation:

$$
r=\frac{\left(A_{1}-A_{0}\right) / A_{0}}{\left(P_{1}-P_{0}\right) / P_{0}}
$$

where $r$ is the ratio of growth; $P_{0}$ is the initial population (2005), population $P_{l}$ is the end of the year (2009), $\mathrm{A}_{0}$ is an urban area in the early years (2005), and $A_{l}$ is the urban area at the end of the year (2009). $A_{I}$ sized city in the area indicated by the formula:

$A_{l}=\frac{r A_{0}\left[P_{1}-P_{0}\right)}{P_{0}}+A_{0}$

where $A_{I}$ depends on the size of the city population $P_{I}$ and the ratio r, if $A_{0}$ and $P_{o}$ are initialized.

Processing and image analysis results showed the character of urban growth. Urban growth pattern was shown on Fig -2 [8]. There are three categories that have been identified, namely infill, expansion, and outlying [18]. Outlying divided into isolated, linear branch, and the branch clustered growth. Ellman defines infill development on the land is developed [18]. Infill development usually occurs where public facilities are available. Expansion growth characterized by urban area the growth of no more than $40 \%$ of existing urban area and this change is the expansion of the area of the city. While outlying growth characterized by a change of open space to be awakened through the space already developed areas.

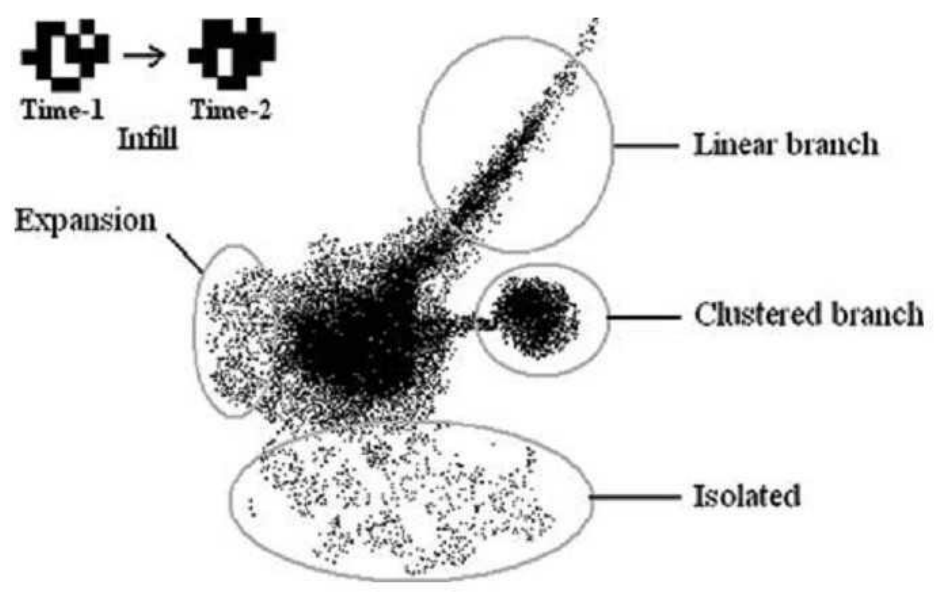

Fig - 2.: Urban growth pattern schemes

\section{RESULTS AND DISCUSSION}

\subsection{Change in land use and population}

The results showed that the land use classification of Banda Aceh in 2005 and 2009 were still dominated by non builtup area of over 3,000 ha (Table 1). Significant increases occurred in the built-up area, which in 2009 reached 2,100 ha. Based on Table - 1, others category of land use also declined to 663 ha in 2009. There were some non built-up areas and others turned into a built-up areas. Land use/cover (LUC) changes shown in Table - 1, which refers to the change detection matrix of the classified image [19]. 
Table - 1: Land use change based on class

\begin{tabular}{lcccccc}
\hline \multirow{2}{*}{ Classes } & \multicolumn{2}{c}{2005} & \multicolumn{2}{c}{2009} & \multicolumn{2}{c}{$2005-2009$} \\
\cline { 2 - 7 } & ha & $\%$ & ha & $\%$ & ha & $\%$ \\
\hline \begin{tabular}{l} 
Built-up area \\
\cline { 2 - 7 } $\begin{array}{l}\text { Non built-up } \\
\text { area }\end{array}$
\end{tabular} & $1,118.89$ & 43.46 & $2,134.90$ & 47.22 & $1,016.01$ & 90.81 \\
\hline \begin{tabular}{l} 
Others \\
\hline
\end{tabular} & $1,432.04$ & 53.35 & 3.199 .84 & 49.58 & -232.2 & -6.77 \\
\hline
\end{tabular}

The analysis of land use in 2005 and 2009 indicate that land use changes have occurred in the period 2005-2009 (Table 3 ). The growth of the built-up area close to a hundred percent within four years, while the non built-up area has declined in extent. The high growth of the built-up area due to the high demand for housing, particularly people who were left homeless by the tsunami. Provision of his houses was part of the process of post-tsunami rehabilitation and reconstruction, where its buildings were done on the land which was also used for settlement before tsunami. The increasing of the built-up areas were also caused by increased development of city infrastructure, such as roads, ports, bridges, office buildings, and markets. Fig - 3 gives an overview of the tsunami-damaged buildings and new building. The further growth was fairly to accommodate rapid population growth between 2005 and 2009. This shows that Banda Aceh was an attractive destination for migrants, either to get to work and education though Banda Aceh has a primary function as the center of government.

Table - 2 shows that the growth of the built-up area far exceeded population growth. The rebuilding of houses in the old settlement land is not matched by the number of people who still exist in these locations, especially in coastal areas of Meuraxa district, so many houses are not inhabited by people . In addition, the construction of new road, widening of road, bridges, and other urban infrastructure supported high growth rate. According to the provisions of Law no. 26 in 2007 about Spatial Planning, that public and non-public open space in the urban area cannot be less than $30 \%$ of the urban area or 1,681 ha in Banda Aceh. With a population growth rate of post-tsunami average of $4.84 \%$ per year, then the growth of urban area 2005-2009 was $22.7 \%$ per year.

The rapid urban growth that occurred between 2005 and 2009 is feared to reduce non built-up area significantly in the coming years, so that the target of providing thirty percent of urban green open space be likely to be made if the city government does not create the right policy to anticipate. This is an important concern in order to realize a sustainable city, which can provide comfort not only for current residents but also residents in the future. In the area of regulation no. 4 of 2009 on spatial planning Banda Aceh from 2009 to 2029, the total population in 2029 was estimated at about 400,000 residents. However, when reviewing the rate of population growth that occurred between 2005 and 2009, the total population of 400,000 residents will be reached in about 2026.

Table - 2: Growth ratio

\begin{tabular}{cccc}
\hline \multirow{2}{*}{ Time Period } & \multicolumn{3}{c}{ Ratio type } \\
\cline { 2 - 4 } & $\left(A_{1}-A_{0}\right) / A_{0}$ & $\left(P_{1}-P_{0}\right) / P_{0}$ & $r$ \\
\hline $2005-2009$ & 0.91 & 0.19 & 4.79 \\
\hline
\end{tabular}

\subsection{Urban growth characters after Tsunami}

The characteristic of growth in this study is defined as the patterns of urban area growth including 3 (three) categories such as infill, expansion, and outlying. Outlying is divided into isolated, linear branch, and clustered branch growth. It can be seen from Fig - 5 and Fig - 6 that the growth characteristic occurred was dominated by expansion. This happened due to the increase of population and its supporting facilities. In general, this pattern happened in the southern part of the city following the road development and river pattern. The category of infill growth is characterized with a more compact form [11]. This category can be seen in the central and eastern parts of the city. Urban area growth leading to the southern part of the city of Banda Aceh was the area which was safe from the tsunami disaster. The growth of built-up area also occurred in the area which had high damages in the western part of Banda Aceh, but it was relatively small. The urban spaces were used to build the buildings for social economic, public facilities, and residential. 


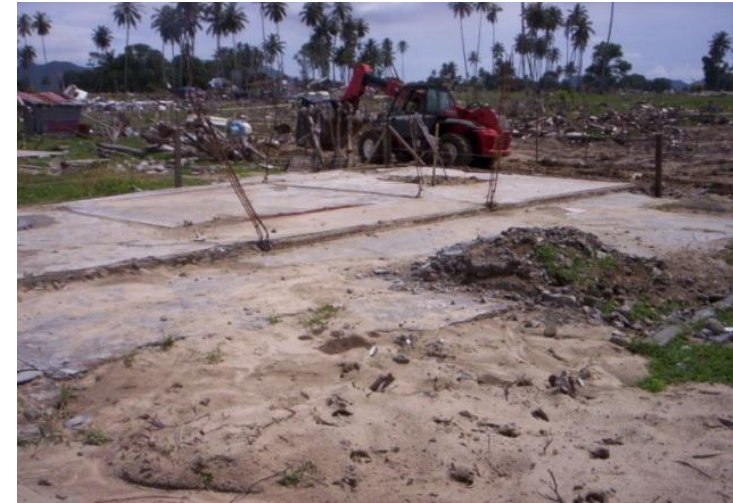

(a)

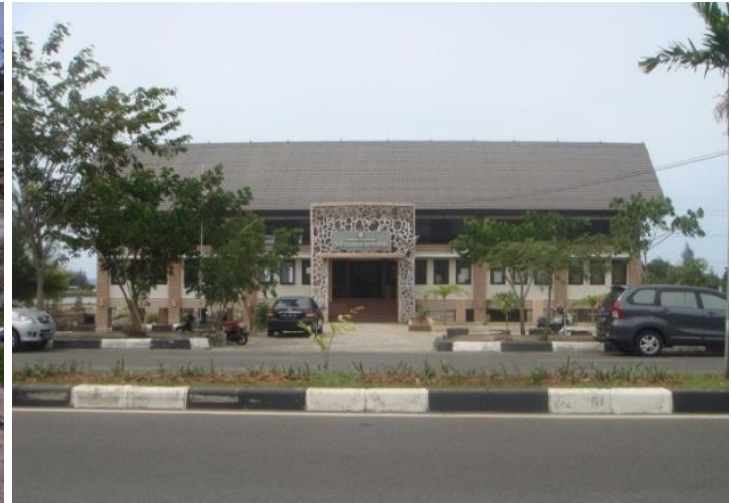

(b)

Fig - 3: Condition of building after the tsunami

(a) building damaged by the tsunami, and (b) new building

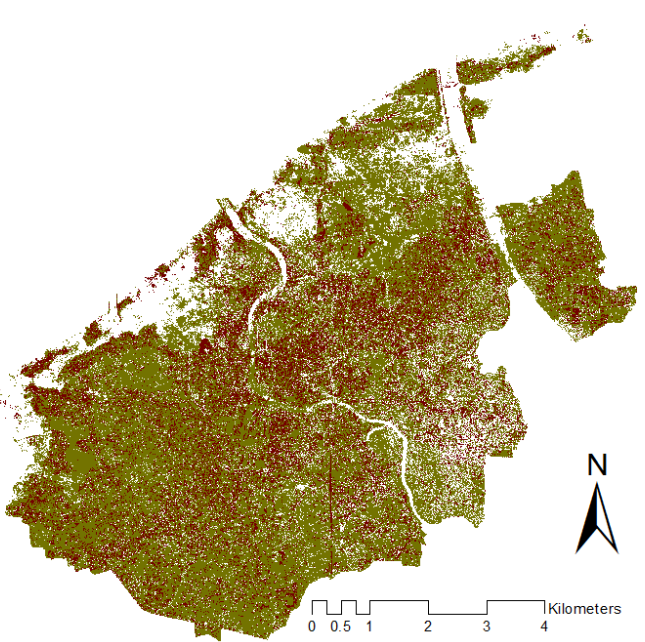

(a)

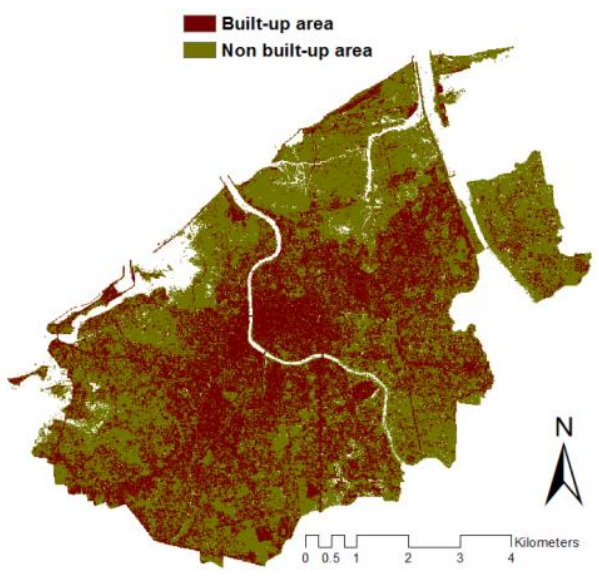

(b)

Fig - 4: Built-up area and non built-up area for 2005 (a) and 2009 (b)

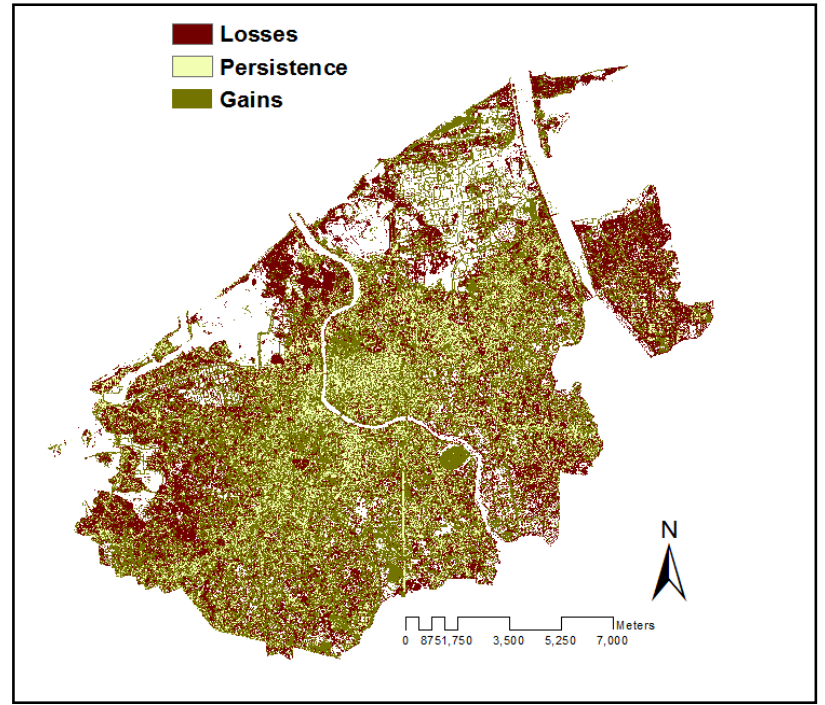

Fig - 5: Losses, persistence, and gains in built-up area

\subsection{The relationship between urban area and socioeconomic growth}

Table - 3 informs that the population growth of the City of Banda Aceh after the tsunami varied very much. The very significant population growth of the Banda Aceh city which reached $23 \%$ occurred in 2007. This growth may have been influenced by the urbanization from various areas in Aceh or outside of Aceh either in relation to employment or doing further study. The replenishment of built-up area after the tsunami (2005-2009) was relatively high.

GDRP is one of the most important indicators to describe the progress of a region. Growth in GDRP at current prices was influenced by rising prices (inflation), for that which we use as a guide the extent of growth of real GDRP at constant prices. Table - 4 shows that GDRP continued to increase from year to year after the tsunami disaster. 
The highest GDRP growth occurred in 2007 which was the peak of the process of rehabilitation and reconstruction in Banda Aceh. The poverty rate dropped to the lowest point reached $6.61 \%$. Many good paying jobs were available in the rehabilitation and reconstruction process. Once the event was over in the end of 2008 a high poverty rate occurred and declined again in 2009. Urban growth that was occurred by the increasing of built-up area and GDRP made poverty rate still fluctuate, though there are many other factors to consider related to the welfare of society and need further research.

Table - 3: Population overview of Banda Aceh after the Tsunami

\begin{tabular}{ccc}
\hline Years & Population & Annual rate of increase \\
\hline 2005 & 177,881 & \\
2006 & 178,380 & 0.3 \\
2007 & 219,659 & 23.1 \\
2008 & 217,918 & -0.8 \\
2009 & 212,241 & -2.6 \\
2010 & 223,446 & 5.3 \\
\hline Source: Central Bureau of Statistic of Aceh, Indonesia, (2013)
\end{tabular}

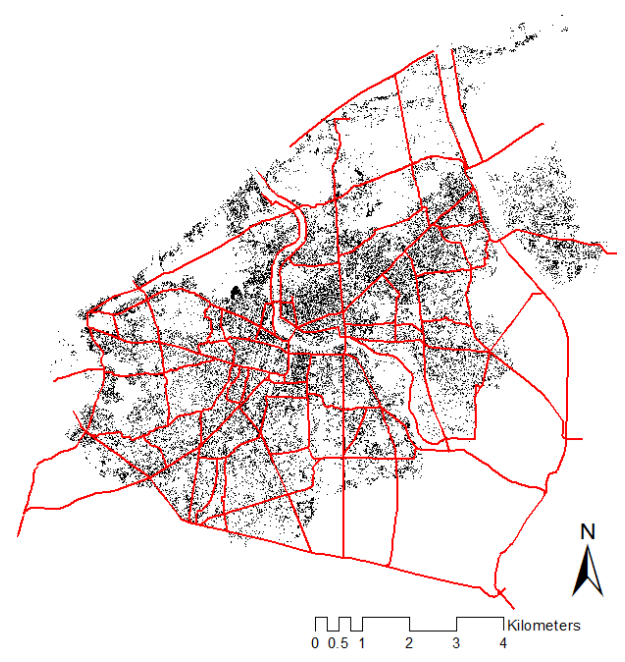

(a)

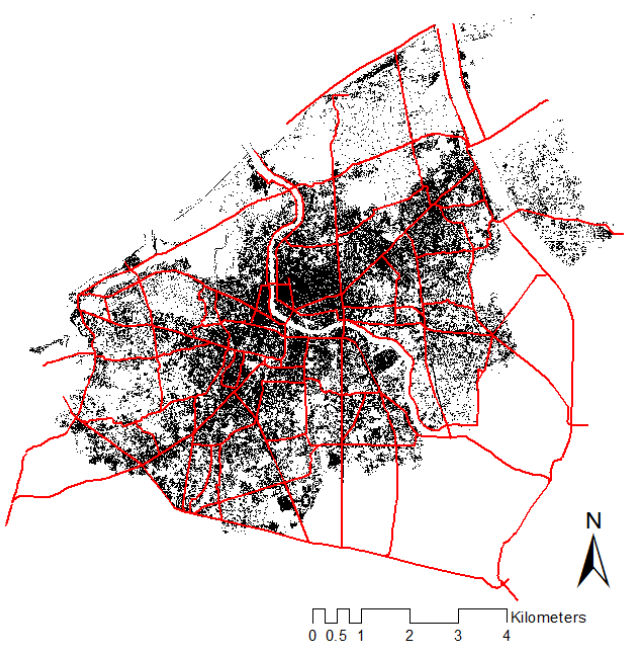

(b)

Fig - 6: Urban growth and road (black is built-up area; red is road pattern)

The results showed that the tsunami of adding more than two million poor people in the five most affected countries of Indonesia, India, Sri Lanka, Maldives, and Thailand also felt the economic impact on local and community levels, particularly the increase in the number of poor people. As a result, poverty-affected areas will be more prevalent [20]. Recovery and reconstruction process of getting people back into homes, livelihoods, education, health services, etc., and national infrastructure development. So it becomes clear that the recovery process made some significant progress in certain sectors that are affected by the tsunami [21]. To that end, program or arrangement of economic recovery should be done on an ongoing basis, so that people become selfsufficient and less dependent on government assistance.

Table - 4: GDRP and poverty growth of Banda Aceh

\begin{tabular}{cccc}
\hline \multirow{2}{*}{ Years } & \multicolumn{2}{c}{ GDRP growth (\%) } & \multirow{2}{*}{ Poverty $(\%)$} \\
\cline { 2 - 3 } & Market price & Constant price & 8.37 \\
2005 & 5.32 & 1.62 & 8.25 \\
2006 & 25.00 & 5.25 & 6.61 \\
2007 & 25.88 & 19.00 & 9.56 \\
2008 & 23.19 & 5.64 & 8.64 \\
2009 & 21.44 & 5.67 & 9.19 \\
2010 & 18.96 & 5.91 &
\end{tabular}

Source: Central Bureau of Statistic of Aceh, Indonesia, (2013) 


\section{CONCLUSION}

The growth of built-up area in the tsunami-affected area between 2005 and 2009 was very high, which nearly doubled. The growth will continue to increase along with the increasing of population. This growth needs to be controlled in order to create sustainable development. It also must be directed properly to minimize damages and victims if the tsunami occurred again.

The characteristic of the urban growth in the area hit by the tsunami was unique because the growth occurred was very rapid, especially between 2005 and 2009. The growth of built-up area were the result of the process of rehabilitation and reconstruction of the areas hit by the tsunami which integrated with new development, either through infill or expansion category. In general, infill-typed urban growth occurred in the city center area, while expansion-typed urban growth occurred in the southern and eastern part of the city, especially in the Sub districts of Lueng Bata, Ulee Kareng, and Syiah Kuala, and in the spatial city planning, these areas belong to the parts of the city which growth should be driven. This urban growth also follows road development.

The urban growth occurred was driven by the increasing of population and the urban socio-economic. This growth has not yet brought good influence in minimizing the poverty rate which was fluctuate and the highest rate happened in 2008. The city government has targeted that in 2013, the poverty rate is projected to go down to $8.58 \%$ and to $4.9 \%$ in 2017.

\section{ACKNOWLEDGEMENT}

We thank Dr. Ronald C. Estoque for technical advice during GIS and remote sensing activities at University of Tsukuba.

\section{REFERENCES}

[1] Bounoua, Lahouari, et, al. 2009. Impact of Urban Growth on Surface Climate: A Case Study in Oran, Algeria, Journal of Applied Meteorology and Climatology 48. 2: 217-231.

[2] Xiaoqing, Wu., Yuanman, H., Hongshi, H.E., Fengming, XI., and Rencang, BU., 2010. Study of Forecast Scenarios for Simulation of Future Urban Growth in Shenyang City Based on SLEUTH Model, Geospatial Information Science 13 (1): 32-39.

[3] Hui-Hui, Feng, et. al. 2011. Scenario Prediction and Analysis of Urban Growth Using SLEUTH Model, Pedosphere 22(2): 206-216, 2012, Published by Elsevier BV and Science Press.

[4] Yu, Nong and Qingyun, Du. 2011. Urban Growth Pattern Modeling Using Logistic Regression, Geospatial Information Science 14(1):62-67, DOI 10.1007/s11806-011-0427-x.

[5] Jantz, Claire A., Scott, J. Goetz, and Mary K. Shelly, 2003. Using SLEUTH Urban Growth Model to
Simulate The Impacts of Future Policy Scenarios on Urban Land Use in Baltimore-Washington Metropolitan Area, Environmental and Planning B: Planning and Design, Volume 30, pages 251-271.

[6] Dietzel, C, Clarke K. C. 2006. The Effect of Disaggregating Land Use Categories in Cellular Automata during Model Calibration and Forecasting [J]. Computers, Environment, and Urban Systems, 30: 78-101.

[7] Vliet, Jasper Van, Roger White, and Suzana Dragicevic, 2009, Modeling Urban Growth Using a Variable Grid Cellular Automaton, Computers, Environment, and Urban System, Elsevier, Science Direct.

[8] Bhatta, Basudeb, 2010, Analysis of Urban Growth and Sprawl for Remote Sensing Data, Springer Heidelberg Dordrecht London New York.

[9] Allen, Jeffrey, and Lu, Kang. 2003. Modeling and Prediction of Future Urban Growth in the Charleston Region of South Carolina: a GIS-based Integrated Approach, Copyright (C) 2003 by the author(s). Published here under license by The Resilience Alliance. Conservation Ecology 8(2): 2. [online] URL:

[10] Liao, Felix HF., and Wei, YH Dennis, 2012, Modeling Determinants of Urban Growth in Dongguan, China: A Spatial Logistic Approach, Stoch Environ Res Risk Assess, DOI 101007/s00477-012-0620y.

[11] Shi, Y., Sun, X., Zhu, X., Li, Y., and Mei, L., 2012, Characterizing growth types and analyzing growth density distribution in response to urban growth patterns in peri-urban areas of Lianyungang City, Landscape and Urban Planning, Journal homepage: www.elsevier.com/locate/landurbplan.

[12] Jelinek, R., Krausmann, E., Gonzales, M., AlvaresGomez, J. A. A., Birkman, J., and Welle, T. 2012. Approaches for Tsunami Risk Assessment and Application to the City of Cadiz, Spain, Nat Hazards (2012) 60:273-293. DOI 10.1007/s11069-011-0009-0.

[13] Burbidge, D., Cummins, P. R., Mlecko, R., and Thio, H. K., 2008. A Probabilistic Tsunami Hazard Assessment for Western Australia, Pure appl. Geophys. 165 (2008) 2059-2088.

[14] Kamigaichi, O., 2009, Tsunami Forecasting and Warning, Encyclopedia of Complexity and Systems Science 2009: 9592-9618.

[15] Gaillard, J. C., et. al, 2008, Ethnic Groups Response to The 26 December 2004 Earthquake and Tsunami in Aceh, Indonesia, Nat Hazards (2008) 47:17-38. DOI 10.1007/s11069-007-9193-3.

[16] Rizkiya, Putra, 2012, The Impact of Tsunami 2004 to the Urban Setting of Banda Aceh, Master Thesis, Fachhochschule Frankfur am Main - University of Applied Sciences.

[17] Musaoglu, N., Tanik, A., \& Kocabas, V. 2005. Identification of land-cover Changes Through Image. Processing and Associated Impacts on Water Reservoir 
Conditions. Environmental Management, 35(2), 220230.

[18] Ellman, T. 1997. Infill: The Cure for Sprawl? Arizona Issue Analysis 146. The Goldwater Institute, Phoenix, AZ.

[19] Geymen, Abdurrahman, and Ibrahim Baz, 2007, Monitoring Urban Growth and Detecting Land-Cover Changes on The Istanbul Metropolitan Area, Anviron Monit Assess (2008) 136:449-459, DOI 10.1007/S10661-007-9699-x.

[20] Hagiwara, A. T., and Sugiyarto, G., 2005, Poverty Impact of the Tsunami: An initial assessment and scenario analysis, paper presented during the 4th PEP Research Network General Meeting, June 13-17, 2005, Colombo, Sri Lanka.

[21] Ratnasooriya, Harsha A. R. R., Samarawickrama, Saman P., and Imamura Fumihiko, 2007, Post tsunami recovery process in Sri Lanka, Journal of Natural Disaster Science, Volume 29, Number 1, 2007, pp2128.

\section{BIOGRAPHIES}

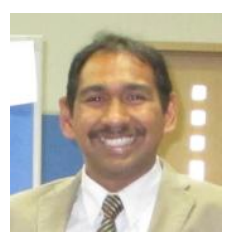

Ashfa Achmad, a senior lecturer at Syiah Kuala University, Banda Aceh. He is currently a Ph.D student in Regional Planning University of Sumatera Utara.

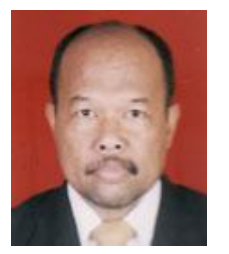

Sirojuzilam, a professor of Regional Planning at University of Sumatera Utara. $\mathrm{He}$ is currently a Head of Graduate Program of Regional Planning.

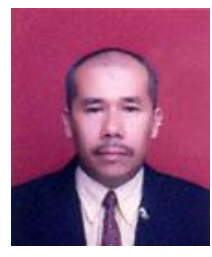

Badaruddin, a professor of Urban Sociology at University of Sumatera Utara. He is currently a Dean of Social and Politics Faculty.

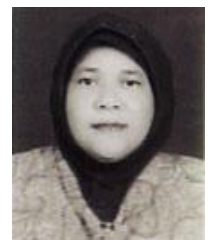

Dwira N. Aulia, a senior lecturer of urban settlement at University of Sumatera Utara. She is currently a Head of Graduate School of Architecture. 